\title{
Switchable Solvent Selective Extraction of Hydrophobic Antioxidants from Synechococcus bigranulatus
}

\author{
Luigi D’Elia, Paola Imbimbo, Davide Liberti, Francesco Bolinesi, Antonino Pollio, Olga Mangoni, \\ Wim Brilman, Giuseppe Olivieri, and Daria Maria Monti*
}

Cite This: ACS Sustainable Chem. Eng. 2021, 9, 13798-13806

Read Online

\section{ACCESS}

џll Metrics \& More

Article Recommendations

Supporting Information

ABSTRACT: Hydrophobic molecules, in particular, carotenoids, have been directly extracted from Synechococcus bigranulatus ACUF680 by means of secondary amine switchable solvent $N$ ethylbutylamine (EBA) without any other pretreatment. EBA was able to extract hydrophobic molecules from both fresh and frozen biomass at the same extent of the conventional procedure (about $20 \%$ of dry biomass). In particular, selective extraction of a zeaxanthin-enriched fraction (green fraction, GF) and a $\beta$-caroteneenriched fraction (orange fraction, OF) was obtained. The ratio between zeaxanthin and $\beta$-carotene was $4.4 \pm 1.5$ for GF, $0.07 \pm$ 0.06 for $\mathrm{OF}$, and about 1 for conventional extraction. These fractions showed in vitro antioxidant activity $\left(\mathrm{IC}_{50}\right.$ values of 0.056 \pm 0.013 and $0.024 \pm 0.008 \mathrm{mg} \mathrm{mL}^{-1}$ for GF and OF, respectively)

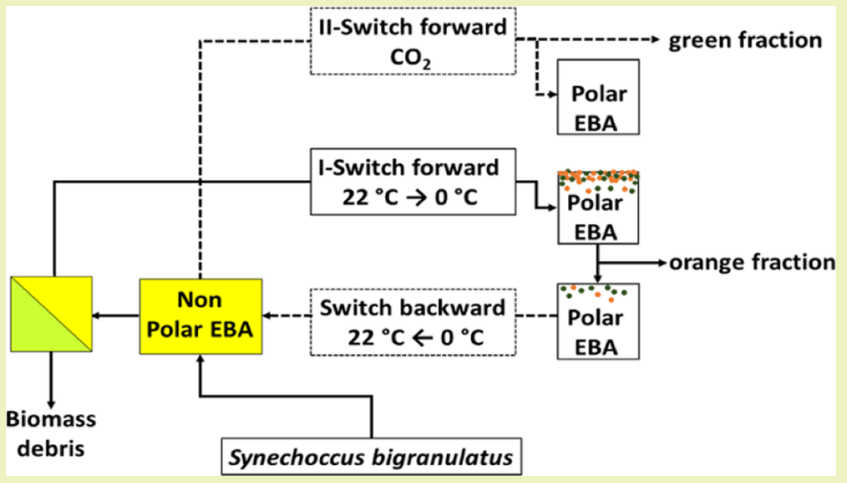
and biocompatibility on immortalized cells. Moreover, OF and GF were able to protect cells from oxidative stress, both before and after thermal treatment. Results clearly indicate that EBA is a good candidate to specifically extract $\beta$-carotene and zeaxanthin from the wet biomass of $S$. bigranulatus without affecting their biological activity. Skipping energy-intensive operations to break the cells and using either fresh or frozen biomass may be the driving factors to use EBA switchable solvent on an industrial scale.

KEYWORDS: antioxidants, switchable solvents, microalgae, N-ethylbutylamine, green chemistry

\section{INTRODUCTION}

In the last decades, the search for energy from renewable sources and the increasing demand of consumers for healthy foods have driven the attention toward microalgae and cyanobacteria. ${ }^{1-4}$ These phototrophic microorganisms can be rich in high-value biological compounds, such as proteins, polysaccharides, polyunsaturated fatty acids, vitamins, and pigments with special biological activities, and thus they can potentially be exploited in several industrial sectors and meet many new consumer wishes. $^{4-6}$

Today, algae and cyanobacteria are used only in the food industry as additives for functional food and as food supplements. In this context, the increasing demand for natural antioxidants, as a healthy alternative to synthetic additives in the food industry, has strengthened the interest for microalgae and cyanobacteria as a valid source of natural antioxidants, such as polyphenols and pigments. ${ }^{7-14}$ Among pigments, carotenoids show the highest antioxidant activity. They are divided into two groups: carotenes and xanthophylls. So far, in the global market, the most commercialized carotenoids are astaxanthin, $\beta$ carotene, lutein, canthaxanthin, lycopene, and zeaxanthin. ${ }^{15}$

Till date, antioxidant extraction is usually performed by using organic solvents. ${ }^{10,16,17}$ However, these benchmark technologies suffer from several drawbacks, making the whole process unsustainable: (i) the use of high amounts of solvent; (ii) the need for a large amount of energy to recover the solvent by evaporation; (iii) the need for more than one extraction step; (iv) the recovery of a mixture of molecules with similar polarity. ${ }^{18-20}$

These drawbacks are even more consistent in the case of antioxidants from microalgae as they already suffer from upstream process costs. ${ }^{21}$ Thus, the optimization of a green extraction technique able to replace conventional procedures seems to be a good starting point for lowering the costs. So far, it has been reported that the new green extraction techniques performed at high pressure, such as supercritical fluid extraction and pressurized liquid extraction, are more sustainable and can be competitive in the effectiveness of the extraction of hydrophobic molecules. ${ }^{22-24}$ However, these innovative tech-

Received: June 28, 2021

Revised: September 23, 2021

Published: October 6, 2021 
nologies show some disadvantages: (i) need of biomass pretreatment often, (ii) difficulty to extract hydrophilic molecules ; (iii) high investment costs, and (iv) difficulty to scale up the process at an industrial scale. ${ }^{20,25}$

In this context, a new class of solvents is emerging: switchable solvents. Switchable solvents (SSs), first reported by Jessop and Liotta, ${ }^{26,27}$ are liquids that can be converted from a nonpolar form to a polar form and vice versa. The switching of the solvent in the hydrophilic form (switch forward) is done by bubbling $\mathrm{CO}_{2}$ through the solvent. The reverse reaction is induced by completely removing $\mathrm{CO}_{2}$ from the system with an inert gas, such as $\mathrm{N}_{2}$, and is enhanced by the heating temperature. ${ }^{28}$ This unique feature allows the solvent, when in the nonpolar form, to extract hydrophobic components, and, when in the polar form, to extract hydrophilic components. Furthermore, when in the polar form or in the nonpolar form, the solvent should be easily separated by the hydrophobic or hydrophilic extracts, respectively. Noteworthy, the circularity of the extraction process on the wet biomass involves a significant reduction in energy consumption because the separation of the solvent from the extract is not performed by evaporation. ${ }^{29,30}$

Recently, a study carried out by $\mathrm{Du}$ et al. reported that the secondary amine $N$-ethylbutylamine (EBA) shows a lower critical solution temperature (LCST) behavior, which means that a change in EBA polarity is possible only by changing the temperature. ${ }^{31}$ This alternative operation is expected to be a cost and energy efficient alternative to the $\mathrm{CO}_{2}$ switching system. ${ }^{31}$ However, the feasibility of the process to effectively and sequentially extract lipids and proteins from microalgae by using a SS characterized by LCST behavior has not been clearly defined yet. $^{32}$

Here, an innovative procedure to selectively extract hydrophobic antioxidants from the cyanobacterium Synechococcus bigranulatus was set up. S. bigranulatus is a good candidate for the production of thermo-resistant antioxidants as it is able to grow at different temperatures. ${ }^{33}$ Experiments were performed by using EBA as the extracting solvent, and three different strategies were tested (Figures S1-S3). Hydrophobic fractions were characterized from a chemical and biological point of view, and the antioxidant activity was tested before and after hightemperature short-time (HTST) pasteurization.

\section{MATERIALS AND METHODS}

Reagents. All solvents, reagents, chemicals, and culture media, unless differently specified, were from Sigma-Aldrich (St Louis, MO, USA).

Microalgal Strain and Culture Conditions. S. bigranulatus was provided by the Algal Collection of the University Federico II (ACUF number 680). ${ }^{34}$ Cells were grown in autotrophic conditions in $800 \mathrm{~mL}$ working volume bubble column photobioreactors in BG11 medium. The photobioreactors were housed in a climate chamber at $37 \pm 1{ }^{\circ} \mathrm{C}$ equipped with fluorescent lamps with a constant light intensity of 300 PAR $\mu \mathrm{mol}_{\text {photons }} \mathrm{m}^{-2} \mathrm{~s}^{-1}$. The aeration of cultures was provided by supplying air at the bottom of the photobioreactors. Cell density was inferred from the absorbance measured at a wavelength of $730 \mathrm{~nm}$. The culture was harvested at the end of the exponential phase, and the biomass concentration was about $0.8 \mathrm{~g} \mathrm{~L}^{-1}$.

Water Content of S. bigranulatus. The water content of the harvested wet microalgae paste after centrifugation was determined by weighing the sample before and after drying at $60^{\circ} \mathrm{C}$ for $24 \mathrm{~h}$. The water content did not change significantly among samples and was $73.1 \pm$ $3.3 \%$.

Protein Extraction and Quantification. The biomass was harvested by centrifugation at $1200 \mathrm{~g}$ for $30 \mathrm{~min}$ at room temperature. Then, $1.5 \mathrm{~g}$ of wet biomass, which corresponds to about $400 \mathrm{mg}$ d.w., was resuspended in $50 \mathrm{mM}$ sodium acetate buffer $\mathrm{pH} 5.5 .^{35}$ Cells were disrupted by ultrasonication (30 s on, $30 \mathrm{~s}$ off, $40 \%$ instrument amplitude) for $45 \mathrm{~min}$ on ice. After centrifugation at $5000 \mathrm{~g}$ at $4{ }^{\circ} \mathrm{C}$ for $30 \mathrm{~min}$, the proteins were recovered in the supernatant and their concentration was measured by the BCA Assay Kit (Thermo Fisher Scientific, Waltham, MA USA).

Conventional Extraction of Total Hydrophobic Molecules. Conventional extraction of hydrophobic molecules from the dry biomass $(\sim 0.3 \mathrm{~g})$ was performed according to the original Bligh \& Dyer (B\&D) method. ${ }^{36}$

Hydrophobic Molecule Extraction by EBA. To extract hydrophobic molecules from $S$. bigranulatus by EBA, the wet biomass $(\sim 1.5$ g) was mixed with EBA in a ratio of $1: 2(\mathrm{wt} / \mathrm{wt})$. The mixture was magnetically stirred at room temperature for $18 \mathrm{~h}$ to ensure extraction of hydrophobic molecules. Then, the mixture was centrifuged at $9000 \mathrm{~g}$ at room temperature, and the supernatant (which contains EBA and hydrophobic molecules) was mixed with water in a ratio of $1: 2(\mathrm{wt} / \mathrm{wt}$ ), forming a biphasic system. Then, three experimental approaches were followed and are schematically represented in Figures S1-S3.

Strategy 1: $\mathrm{CO}_{2}-\mathrm{N}_{2}$ Switching Method. $\mathrm{CO}_{2}$ was insufflated into the biphasic system for $30 \mathrm{~min}$ at $2 \mathrm{vvm}$ (volume volume per minute) to allow EBA to switch in its polar form (switching forward). The sample was centrifuged at $9000 \mathrm{~g}$ at room temperature. At the end of centrifugation, EBA and water formed a homogeneous phase (water phase) with a small lipid layer on the top. The hydrophobic molecules were recovered by chloroform. The total amount of the extracted product was measured gravimetrically (after evaporating the solvent) and reported as a percentage of the algae dry weight.

To extract hydrophilic molecules, the water phase was incubated in the presence of the residual biomass for $2 \mathrm{~h}$ at room temperature. The sample was centrifuged at $9000 \mathrm{~g}$ at $0{ }^{\circ} \mathrm{C}$ for $10 \mathrm{~min}$. Then, to recover the extracted hydrophilic molecules, $\mathrm{N}_{2}$ was bubbled through the supernatant to remove $\mathrm{CO}_{2}$ (switch back) and to allow EBA returning in the hydrophobic form. The sample was centrifuged at $9000 \mathrm{~g}$ at room temperature. However, no formation of the two phase system was observed.

Strategy 2: Temperature switching method (LCST). The supernatant was cooled to $0{ }^{\circ} \mathrm{C}$ for $2 \mathrm{~h}$ to allow the switch of EBA in its polar form. The sample was centrifuged at $9000 \mathrm{~g}$ at $0{ }^{\circ} \mathrm{C}$. The result was a water phase with a hydrophobic layer on the top of the tube. This layer consisted of two parts, a green layer on the top and an orange layer on the wall of the tube. To recover the hydrophobic phase, chloroform was added, mixed, and centrifuged at $9000 \mathrm{~g}$ at $0{ }^{\circ} \mathrm{C}$ for $10 \mathrm{~min}$. A two-phase system was observed with the hydrophobic molecules on the bottom. The total amount of the extracted products was measured gravimetrically (after evaporating the solvent) and reported as a percentage of the algae dry weight. To extract hydrophilic molecules, the water phase was incubated in the presence of the residual biomass for $2 \mathrm{~h}$ at $0{ }^{\circ} \mathrm{C}$. The sample was centrifuged at $9000 \mathrm{~g}$ at $0{ }^{\circ} \mathrm{C}$ for $10 \mathrm{~min}$. Then, to collect hydrophilic molecules, the supernatant was heated to $22{ }^{\circ} \mathrm{C}$ to allow EBA switching back to the nonpolar form. The sample was centrifuged at $9000 \mathrm{~g}$ at $0{ }^{\circ} \mathrm{C}$ for $10 \mathrm{~min}$ to allow the formation of two phases. The aqueous fraction containing hydrophilic molecules was collected, the total proteins were determined by the BCA assay, and then an sodium dodecyl sulfate-polyacrylamide gel electrophoresis (SDS-PAGE) analysis was performed.

Strategy 3: Switch Forward-Switch Back-Switch Forward. To avoid the use of chloroform during the recovery of the hydrophobic molecules, heptane was used. By this procedure, the orange layer was recovered after centrifugation at $9000 \mathrm{~g}$ at $0{ }^{\circ} \mathrm{C}$. The green layer was found to be mixed again with EBA. To recover them, a double switch was needed. Thus, the system was heated to $22{ }^{\circ} \mathrm{C}$ to allow EBA switching back to the nonpolar form. The sample was centrifuged at $9000 \mathrm{~g}$ at room temperature to allow the formation of two phases. The upper phase contained EBA and the hydrophobic molecules. The upper phase was transferred to a new tube and mixed with water in a ratio of 1:2 (wt/wt) forming a biphasic system. Then, $\mathrm{CO}_{2}$ was insufflated into the system for $30 \mathrm{~min}$ at $2 \mathrm{vvm}$, and the sample was centrifuged at $9000 \mathrm{~g}$ at room temperature to recover the green fraction (GF) on the top by chloroform. 
The total amount of the extracted products was measured gravimetrically (after evaporating the solvent) and reported as a percentage of the algae dry weight.

In a parallel experiment, heptane was replaced by methanol.

ABTS Assay. The in vitro antioxidant activity of the orange fraction (OF) and GF was evaluated by the 2,2' -azinobis-(3-ethylbenzothiazoiline-6-sulfonic acid) ABTS assay according to Rigano et al. with some modifications. ${ }^{37}$ Briefly, $7.4 \mathrm{mM} \mathrm{ABTS}{ }^{\bullet+}$ was mixed with $140 \mathrm{mM}$ $\mathrm{K}_{2} \mathrm{~S}_{2} \mathrm{O}_{8}$, and the solution was stabilized for $16 \mathrm{~h}$ at room temperature in the dark. The mixture was then diluted with deionized water to obtain an absorbance of $0.70 \pm 0.02$ unit at $734 \mathrm{~nm}$ using a spectrophotometer. Each extract $(50 \mu \mathrm{L})$ was allowed to react with $250 \mu \mathrm{L}$ of diluted $\mathrm{ABTS}^{\bullet+}$ solution for $7 \mathrm{~min}$, and then the absorbance was read at 734 $\mathrm{nm}$. The standard curve was linear between 0 and $20 \mu \mathrm{M}$ Trolox. Results are expressed as $\mathrm{IC}_{50}\left(\mathrm{mg} \mathrm{mL}^{-1}\right)$, that is, the concentration required to scavenge $50 \%$ of free radical $\mathrm{ABTS}$.

Cell Culture and Biocompatibility Assay. Human immortalized keratinocytes (HaCaT, Innoprot, Spain) and immortalized murine fibroblasts (BALB/c 3T3, ATCC, Manassas, VI, USA) were cultured in $10 \%$ fetal bovine serum in Dulbecco's modified Eagle's medium in the presence of $1 \%$ antibiotics and $2 \mathrm{mM}$ L-glutamine in a $5 \% \mathrm{CO}_{2}$ humidified atmosphere at $37^{\circ} \mathrm{C}$. HaCaT cells were seeded in 96-well plates at a density of $2 \times 10^{3}$ cells well $^{-1}$, and BALB/c 3 T 3 were seeded at a density of $3 \times 10^{3}$ cells well $^{-1}$. $24 \mathrm{~h}$ after seeding, increasing concentrations of OF and GF (from 10 to $200 \mu \mathrm{g} \mathrm{mL}^{-1}$ ) were added to the cells for $48 \mathrm{~h}$. At the end of the incubation, cell viability was measured by the tetrazolium salt colorimetric assay (MTT assay), as previously described. ${ }^{38}$ Cell survival was expressed as the percentage of viable cells in the presence of the extracts compared to control cells (represented by the average obtained between untreated cells and cells supplemented with the highest concentration of the buffer). Each sample was tested in three independent analysis, each carried out in triplicate.

HTST Pasteurization. Thermal pasteurization was performed accordingly to the protocol reported by Ferraro et al. ${ }^{39}$ Briefly, OF and GF were heated at $75{ }^{\circ} \mathrm{C}$ in a water bath. After $10 \mathrm{~min}$ incubation, the samples were transferred to a second water bath at $20{ }^{\circ} \mathrm{C}$ and then stored at $4{ }^{\circ} \mathrm{C}$ until analysis.

Cellular Reactive Oxygen Species Assay. To evaluate the protective effect of OF and GF against oxidative stress, DCFDA assay was carried out according to the protocol reported by Petruk et al. ${ }^{40}$ with some modifications. Briefly, $24 \mathrm{~h}$ after seeding, the cells were incubated in the presence of $25 \mu \mathrm{g} \mathrm{mL}^{-1}$ of either raw or pasteurized OF and GF for $2 \mathrm{~h}$ and irradiated by UVA light for $10 \mathrm{~min}\left(100 \mathrm{~J} \mathrm{~cm}^{-2}\right)$. Fluorescence intensity of the probe $\left(2^{\prime}, 7^{\prime}\right.$-dichlorofluorescein, DCF) was measured at an emission wavelength of $525 \mathrm{~nm}$ and an excitation wavelength of $488 \mathrm{~nm}$ using a PerkinElmer LS50 spectrofluorometer. Emission spectra were acquired at a scanning speed of $300 \mathrm{~nm} \mathrm{~min}{ }^{-1}$ with a 5-slit width for both excitation and emission. Reactive oxygen species (ROS) production was expressed as the percentage of DCF fluorescence intensity of the samples under test compared to untreated samples. Three independent experiments were carried out, each one with three determinations.

Pigment Identification by High-Performance Liquid Chromatography. For the determination of the pigment content, the extracts were resuspended in $100 \%$ methanol and analyzed by isocratic high-performance liquid chromatography (HPLC) (Hewlett Packard, 1100 Series) in a reverse phase (C8 column $3 \mu \mathrm{m}$ Hyperloop MOS, 10 $\mathrm{cm}, 4.6 \mathrm{~mm}$ internal diameter, Shandon) as described by Vidussi et al. ${ }^{41}$ The mobile phase consisted of $\mathrm{MeOH}: 0.5 \mathrm{~N}$ aqueous ammonium acetate, $70: 30 \% \mathrm{v} / \mathrm{v}$ (solvent $\mathrm{A}$ ) and $\mathrm{MeOH}$ (solvent $\mathrm{B}$ ), with a gradient (time expressed in minutes; percent of solvent A-percent of solvent $B$ ): $0: 75-25 ; 1: 50-50 ; 15: 0-100$; and 19:75-25. For the determination of chlorophylls and carotenoids, a spectrophotometer with a diode array detector was set at $440 \mathrm{~nm}$, making it possible to determine the absorption spectrum of the $350-750 \mathrm{~nm}$ interval for each peak in order to check the purity of single pigments. The calibration of the instrument was carried out using external standard pigments provided by the International Agency for $14 \mathrm{C}$ determination-VKI Water Quality Institute. The identification of pigments was based considering the retention time, spectral characteristics, and chromatography with certified commercial standards (International Agency for 14C determinations, Denmark). Quantification was based on the absorbance at $440 \mathrm{~nm}$ and the factor response (peak area/pigment concentration) value for each pigment, as described in the study by Mantoura and Repeta. ${ }^{42}$

Statistical Analysis. Samples were analyzed in triplicate. Results are presented as mean of results (means \pm SD) and compared by oneway ANOVA according to the Bonferroni's method (post hoc) or $t$-test using Graphpad Prism for Windows, version 6.01.

\section{RESULTS AND DISCUSSION}

Extraction and Recovery of Hydrophobic Molecules from Synechococcus bigranulatus through SSs. To verify the ability of EBA SS to extract hydrophobic molecules from the frozen wet biomass of $S$. bigranulatus, a direct comparison with a reference extraction method (B\&D) on dry biomass was performed. Thus, frozen wet biomass was mixed with the solvent. Then, to separate hydrophobic molecules from EBA, the solvent was switched to the hydrophilic form (switch forward) by two procedures: (i) by bubbling $\mathrm{CO}_{2}$ through the system ( $\mathrm{SS}-\mathrm{CO}_{2}$ switch-forward, reported in Figure S1) and (ii) by decreasing the temperature (SS-LCST switch-forward, LCST, reported in Figure S2).

The extracted hydrophobic molecules were measured gravimetrically and reported as percentage with respect to the dry weight biomass (Figure 1). Results clearly show that EBA was

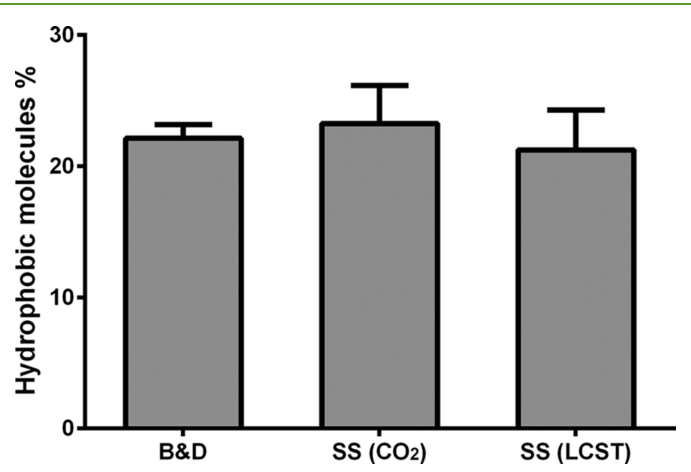

Figure 1. Hydrophobic molecules from S. bigranulatus biomass. Yields are reported as \% with respect to the dry weight biomass. SS $\left(\mathrm{CO}_{2}\right)$ refers to extraction by SS and $\mathrm{CO}_{2}$; SS (LCST) refers to extraction by SS and LCST. Results are reported as means \pm SD of at least three independent experiments.

able to extract hydrophobic molecules from the algae at the same extent of the $\mathrm{B} \& \mathrm{D}$ procedure. This result indicates that it is possible to obtain hydrophobic molecules starting from a wet biomass, thus potentially reducing the costs of the whole process, which are affected by drying, milling, and temperature.

Protein Extraction. After the extraction of hydrophobic molecules, EBA solvent, in its polar form, was used to extract proteins on the residual biomass, as described in the Materials and Method section. In this case, ultrasounds were used as the reference procedure. When the $\mathrm{SS}-\mathrm{CO}_{2}$ switch-forward strategy was performed, no formation of the two-phase system was observed after $\mathrm{N}_{2}$ insufflation and temperature increase, probably due to stripping of switched (hydrophobic) EBA from the solution by the warm $\mathrm{N}_{2}$ flow. In the case of SS-LCST switch-forward strategy, in which only the temperature was changed, a hydrophilic phase was recovered and characterized. According to the BCA assay, the SS $\left(\mathrm{LCST}-\mathrm{CO}_{2}\right)$ method allowed to recover about $10 \%$ proteins, a value 3 -fold lower than 
in the case of ultrasonication. However, when the samples were analyzed by SDS-PAGE, no proteins were observed in the sample SS (LCST- $\mathrm{CO}_{2}$ ) (Figure 2), thus suggesting that, during

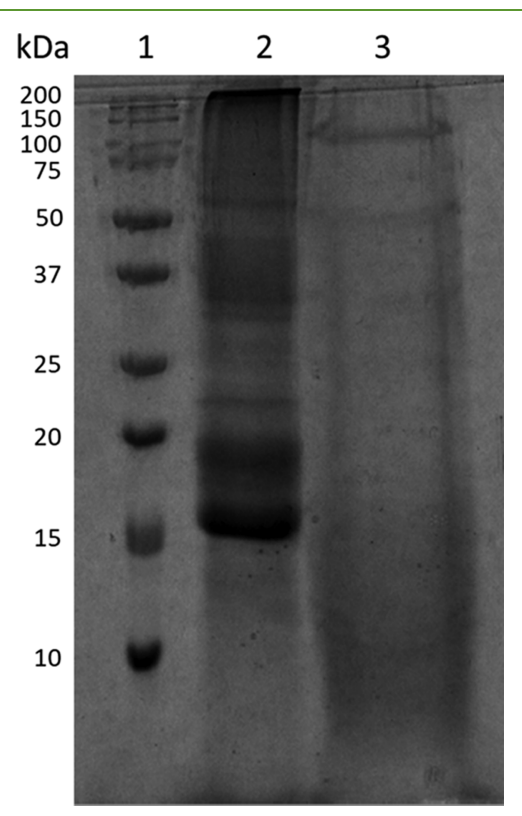

Figure 2. Proteins extracted from S. bigranulatus. SDS-PAGE analysis of proteins extracted by ultrasounds and SS $\left(\right.$ LCST- $\left.\mathrm{CO}_{2}\right)$ extraction. Lane 1: molecular weight markers; lane 2: soluble proteins extracted by ultrasounds $(30 \mu \mathrm{g})$; lane 3 : soluble proteins extracted by EBA $(30 \mu \mathrm{g})$. SDS-PAGE was stained by Blue Coomassie.

the extraction with nonpolar EBA, proteins may be degraded and/or unfolded and precipitate in the centrifugation step. The results indicate that the yield calculated by the BCA procedure is affected by the presence of EBA itself. In a parallel experiment, the polar form of EBA was used on the raw biomass to verify its ability to extract hydrophilic molecules. However, no hydrophilic molecules were obtained, maybe because polar EBA was not able to destroy the biomass in the absence of any physical and/or mechanical treatment (data not shown). On the other hand, nonpolar EBA better penetrates the biomass of microalgae with a fragile cell wall, such as the one of $S$. bigranulatus. The cyanobacterium has a cell wall similar to that of Gram-negative bacteria but equipped with a thick peptidoglycan layer. ${ }^{43,44}$ Moreover, the absence of cellulose renders the process feasible under mild conditions.

Switch Forward-Switch Back-Switch Forward Strategy. In order to replace chloroform with a green solvent, a third strategy was set up (Figure S3), and the detailed procedure is described in the Materials and Method section. The replacement of chloroform with heptane allowed to recover an OF, whereas the green layer was mixed again with EBA. Thus, the GF was recovered after a second cycle of switch-forward by using chloroform. Fresh and frozen (stored at $-20{ }^{\circ} \mathrm{C}$ ) biomass were analyzed in parallel experiments. As reported in Figure 3, the yields of OF and GF do not show any significant difference between the two starting materials. This result suggests that the extraction can be performed according to the experimental purpose, that is, on either just harvested or stored biomass. Thus, from an industrial point of view, even if storing the biomass can be a cost, it could allow a more flexible scheduling of the downstream process.

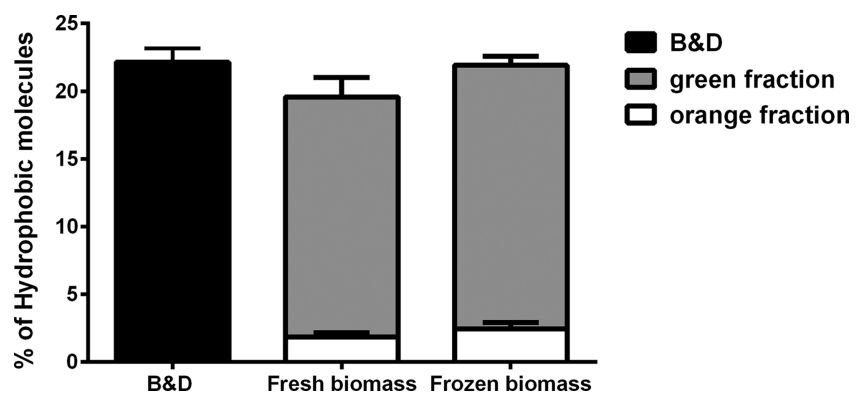

Figure 3. Yields of hydrophobic molecules in OF and GF. Yields are referred to extracts from fresh or frozen biomass and reported as \% with respect to the dry weight biomass. Black bar refers to B\&D; gray bars refer to the GF; white bars refer to the OF. Results are reported as means $\pm \mathrm{SD}$ of at least three independent experiments.

HPLC Analysis. HPLC analysis was performed to identify the molecules present in OF and GF. Results are reported in Figure 4 and they clearly show that $\mathrm{OF}$ is enriched in $\beta$-carotene, whereas GF is enriched in zeaxanthin. Indeed, when the ratio zeaxanthin/ $\beta$-carotene was measured in both fractions, a ratio of $0.07 \pm 0.06$ was found in the OF and $4.4 \pm 1.5$ in the GF, whereas the ratio in the raw extract obtained by conventional extraction was about 1 . In particular, zeaxanthin values ranged between 1.3 and $20.7 \mathrm{mg} \mathrm{g}_{\mathrm{dw}}{ }^{-1}$ in the GF, whereas $\beta$-carotene ranged between 0.3 and $0.6 \mathrm{mg} \mathrm{g}_{\mathrm{dw}}{ }^{-1}$ in the OF. A mean value of $0.37 \mathrm{mg} \mathrm{g}_{\mathrm{dw}}{ }^{-1}$ was observed instead for both molecules in the extract obtained by a conventional method, suggesting a better extraction yield of at least zeaxanthin with EBA with respect to conventional methods.

ABTS Assay. To verify if the extraction technique affected the biological activity of OF and GF, the in vitro antioxidant activity was tested by the ABTS assay. Results are shown in Figure 5 and clearly indicate that both fractions had antioxidant activity. The $\mathrm{IC}_{50}$ values, which correspond to the concentration of the extract that can inhibit $50 \%$ of the radical, were $0.024 \pm$ 0.008 and $0.056 \pm 0.013 \mathrm{mg} \mathrm{mL}^{-1}$ for the $\mathrm{OF}$ and $\mathrm{GF}$, respectively.

Evaluation of the Biocompatibility of OF and GF on Eukaryotic Cells. The biocompatibility of OF and GF was evaluated by the MTT assay on two immortalized eukaryotic cell lines: $\mathrm{HaCaT}$ (human keratinocytes) and BALB/c 3T3 (murine fibroblasts). Cells were incubated in the presence of each extract for $48 \mathrm{~h}$, and cell survival was determined as described in the Materials and Methods section. As shown in Figure 6, the GF did not show cell mortality on both cell lines tested up to $200 \mu \mathrm{g}$ $\mathrm{mL}^{-1}$ (A,B), whereas the OF (C,D) showed a low level of toxicity only on $\mathrm{HaCaT}$ cells $\left(\mathrm{IC}_{50}\right.$ value of $\left.152 \pm 7 \mu \mathrm{g} \mathrm{mL}^{-1}\right)$. Noteworthy, the solvent used to recover the OF is important as when methanol was used, cell mortality was achieved at a very low concentration of the extract, with an $\mathrm{IC}_{50}$ value of $31 \pm 8 \mu \mathrm{g}$ $\mathrm{mL}^{-1}$ and $43 \pm 4 \mu \mathrm{g} \mathrm{mL}^{-1}$ on $\mathrm{HaCaT}$ cells and BALB/c $3 \mathrm{~T} 3$ cells, respectively (E,F).

Evaluation of Antioxidant Activity of OF and GF on Eukaryotic Cells. To verify if the two extracts could be used in the food industry and if they are resistant to high-temperature treatments, a comparison between the antioxidant activity of raw and pasteurized extracts (i.e., HTST pasteurization) was performed on a cell-based system. $\mathrm{HaCaT}$ cells were stressed by UVA, chosen as a source of oxidative stress. Cells were incubated for $2 \mathrm{~h}$ with $25 \mu \mathrm{g} \mathrm{mL}^{-1}$ of each extract prior to UVA exposure. Then, the DCFDA probe was used to measure the 

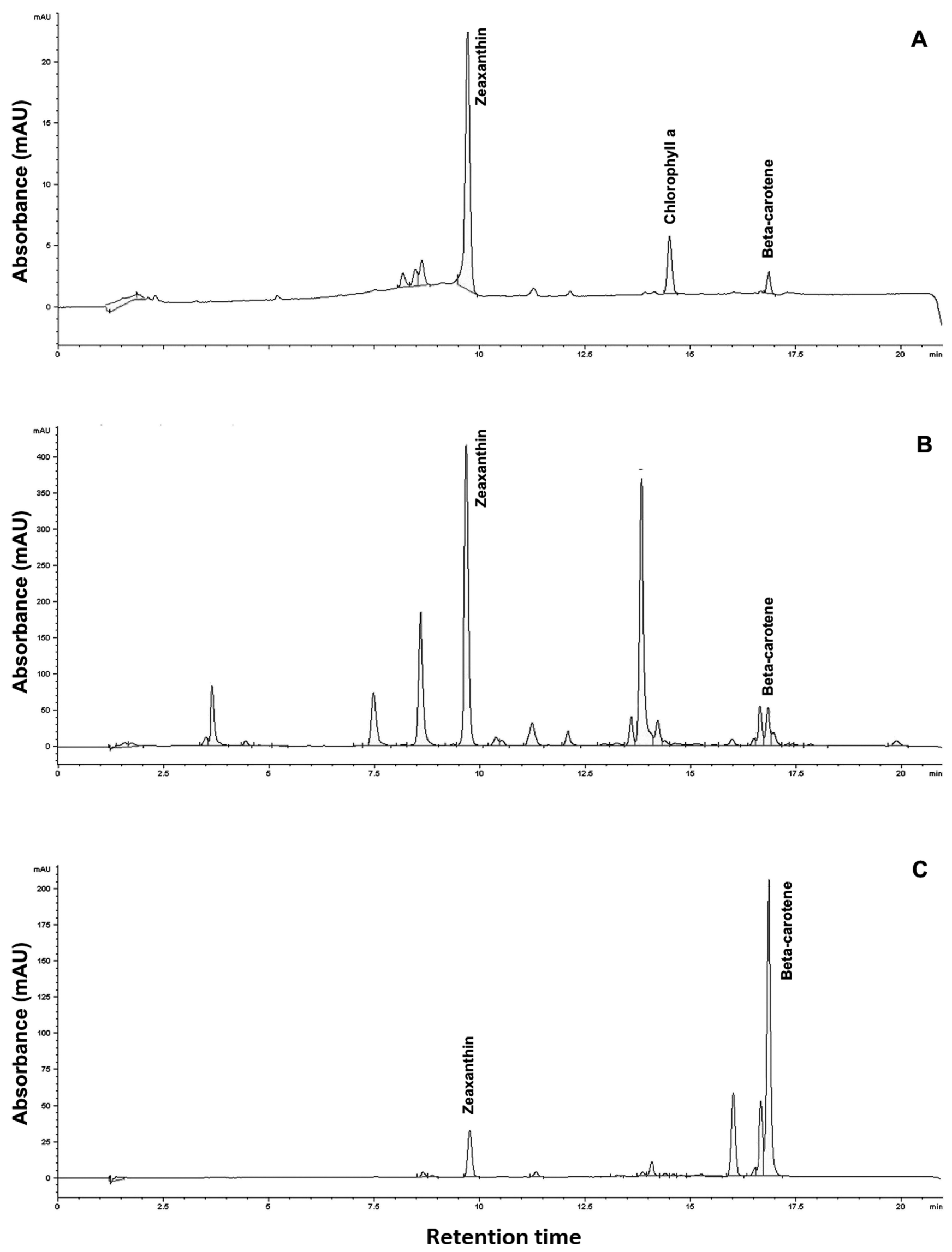

Figure 4. Representative HPLC chromatograms of antioxidants extracted from S. bigranulatus. (A) Raw extract obtained by conventional extraction, (B) GF, and (C) OF. 

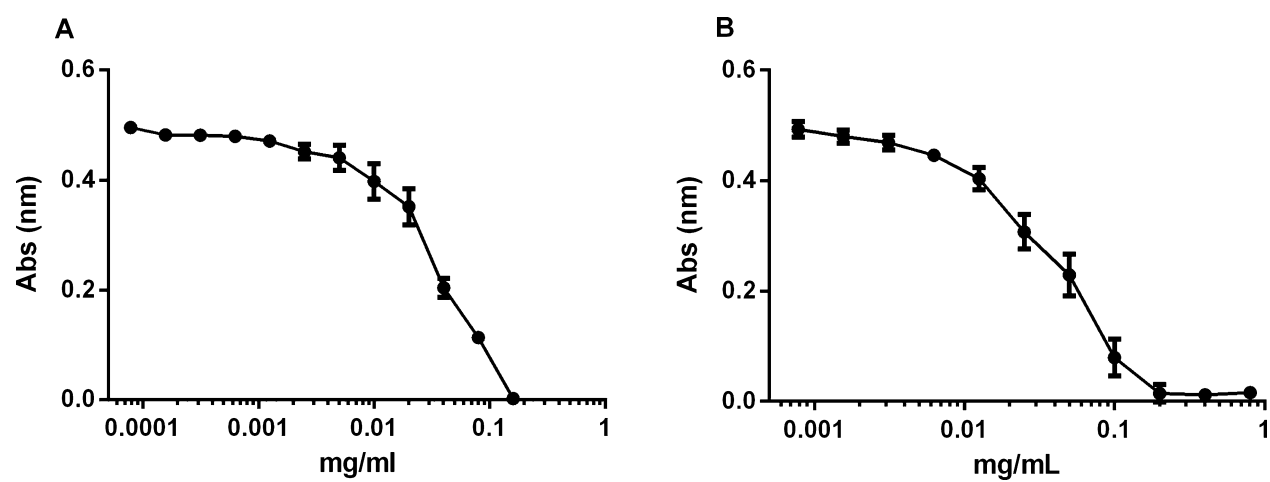

Figure 5. ABTS assay on OF and GF. The ABTS scavenging activity of OF (A) and GF (B) $\left(\mathrm{mg} \mathrm{mL}^{-1}\right)$ from S. bigranulatus. Data shown are means \pm $\mathrm{SD}$ of three independent experiments.
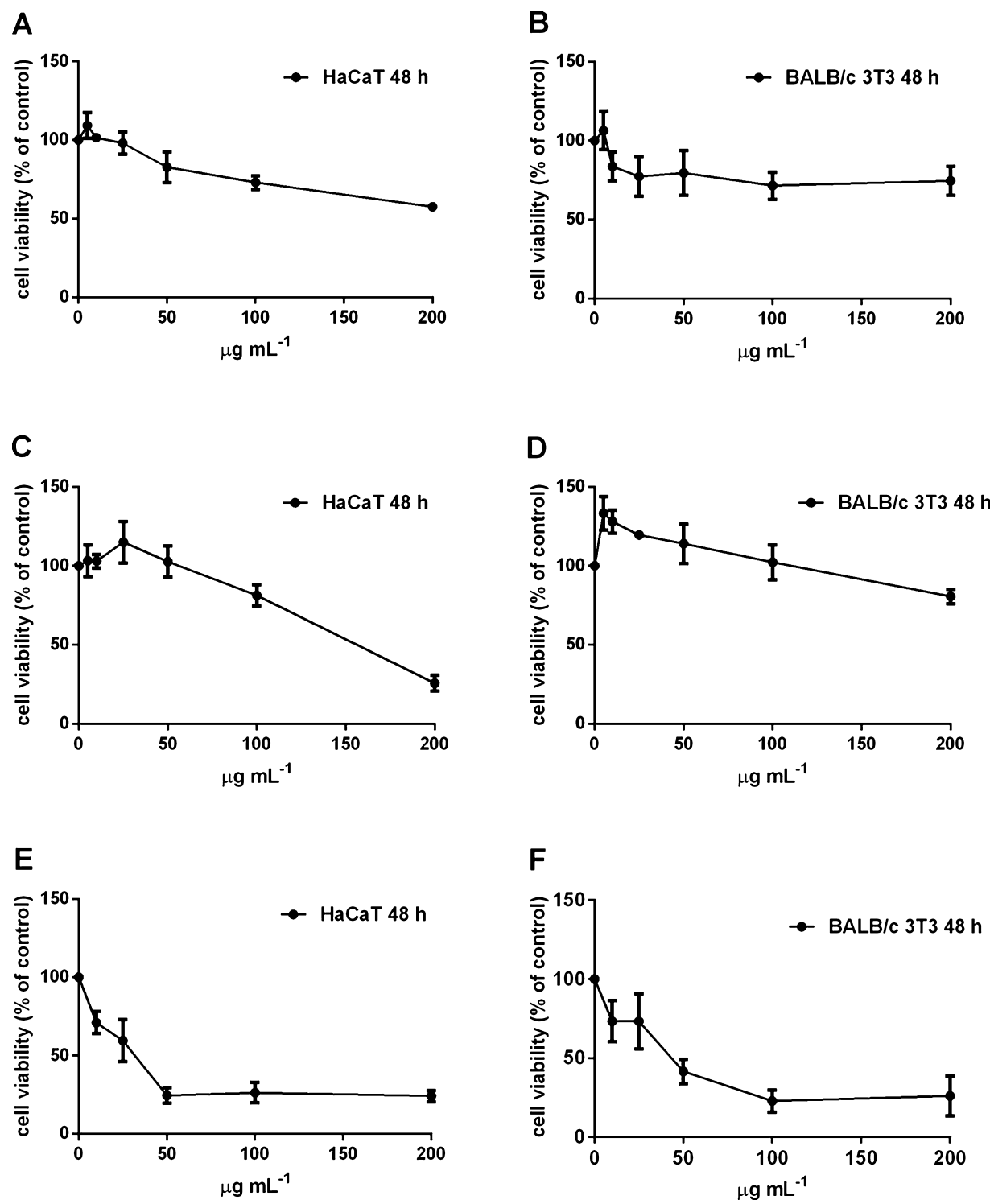

Figure 6. Cell viability of OF and GF on eukaryotic cells. $\mathrm{HaCaT}$ and BALB/c $3 \mathrm{~T} 3$ were incubated for $48 \mathrm{~h}$ with increasing concentrations $(10-200 \mu \mathrm{g}$ $\mathrm{mL}^{-1}$ ) of GF (A,B), OF collected with heptane (C,D), and OF collected with methanol (E,F). Cell viability was assessed by the MTT assay, and cell survival expressed as a percentage of viable cells in the presence of the extracts under test with respect to control cells grown in the absence of the extracts. Data shown are means \pm SD of three independent experiments.

ROS levels. As shown in Figure 7, no effect on ROS levels was observed when the cells were incubated with either the raw $O F$ or GF extracts, whereas when the cells were incubated with pasteurized orange and green extracts, an increase in intracellular ROS levels is observed in the absence of any treatment. UVA induced a significant increase in intracellular ROS levels 


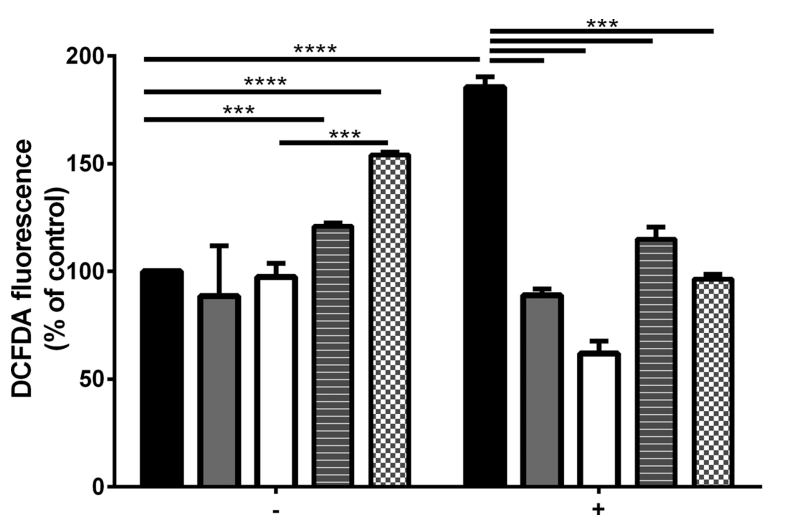


Giuseppe Olivieri - Bioprocess Engineering Group, Wageningen University and Research, Wageningen 6700AA, the Netherlands

Complete contact information is available at:

https://pubs.acs.org/10.1021/acssuschemeng.1c04400

\section{Notes}

The authors declare no competing financial interest.

\section{REFERENCES}

(1) Spolaore, P.; Joannis-Cassan, C.; Duran, E.; Isambert, A. Commercial Applications of Microalgae. J. Biosci. Bioeng. 2006, 101, 87-96.

(2) Zhu, L. Biorefinery as a Promising Approach to Promote Microalgae Industry: An Innovative Framework. Renewable Sustainable Energy Rev. 2015, 41, 1376-1384.

(3) Ruiz, J.; Olivieri, G.; de Vree, J.; Bosma, R.; Willems, P.; Reith, J. H.; Eppink, M. H. M.; Kleinegris, D. M. M.; Wijffels, R. H.; Barbosa, M. J. Towards Industrial Products from Microalgae. Energy Environ. Sci. 2016, 9, 3036-3043.

(4) Draaisma, R. B.; Wijffels, R. H.; Slegers, P.; Brentner, L. B.; Roy, A.; Barbosa, M. J.; Elsevier Current Trends April, 2013, 24, pp 169177. DOI: $10.1016 /$ j.copbio.2012.09.012.Food Commodities from Microalgae. Curr. Opin. Biotechnol.

(5) Dolganyuk, V.; Belova, D.; Babich, O.; Prosekov, A.; Ivanova, S.; Katserov, D.; Patyukov, N.; Sukhikh, S. Microalgae: A Promising Source of Valuable Bioproducts. Biomolecules 2020, 10, 1153.

(6) Pulz, O.; Gross, W. Valuable Products from Biotechnology of Microalgae. Appl. Microbiol. Biotechnol. 2004, 65, 635-648.

(7) Shebis, Y.; Iluz, D.; Kinel-Tahan, Y.; Dubinsky, Z.; Yehoshua, Y. Natural Antioxidants: Function and Sources. Food Nutr. Sci. 2013, 04, 643-649.

(8) Ribeiro, J. S.; Santos, M. J. M. C.; Silva, L. K. R.; Pereira, L. C. L.; Santos, I. A.; da Silva Lannes, S. C.; da Silva, M. V. Natural Antioxidants Used in Meat Products: A Brief Review. Meat Science; Elsevier Ltd. February, 2019, 148, pp 181-188.

(9) Goiris, K.; Muylaert, K.; Fraeye, I.; Foubert, I.; De Brabanter, J.; De Cooman, L. Antioxidant Potential of Microalgae in Relation to Their Phenolic and Carotenoid Content. J. Appl. Phycol. 2012, 24, 1477-1486.

(10) Lourenço, S. C.; Moldão-Martins, M.; Alves, V. D. Antioxidants of Natural Plant Origins: From Sources to Food Industry Applications. Molecules 2019, 24, 4132.

(11) Zhao, Z.; Rasool, M. A.; Chen, C.; Ma, S.; Wang, L.; Huang, G. Identification and Screening of Multiple Tropical Microalgal Strains for Antioxidant Activity in Vitro. Food Biosci. 2020, 36, 100649.

(12) Villalobos-Delgado, L. H.; Mateo, J.; Caro, I.; Leal Ramos, M.-Y.; Mendez, N. G.; Cansino, R. G.; González Mondragón, E. G. Sustainable Meat Production and Processing; Elsevier, 2019, pp 207-236. DOI: 10.1016/b978-0-12-814874-7.00011-0.Natural Antioxidants in Fresh and Processed Meat

(13) Liu, X.; Luo, G.; Wang, L.; Yuan, W. Optimization of Antioxidant Extraction from Edible Brown Algae Ascophyllum nodosum Using Response Surface Methodology. Food Bioprod. Process. 2019, 114, 205-215.

(14) Sansone, C.; Brunet, C. Promises and Challenges of Microalgal Antioxidant Production. Antioxidants 2019, 8, 199.

(15) Jacob-Lopes, E.; Maroneze, M. M.; Deprá, M. C.; Sartori, R. B.; Dias, R. R.; Zepka, L. Q. Current Opinion in Food Science; Elsevier Ltd February, 2019, 25, pp 1-7. DOI: 10.1016/j.cofs.2018.12.003.Bioactive Food Compounds from Microalgae: An Innovative Framework on Industrial Biorefineries

(16) Hidalgo, G.-I.; Almajano, M. Red Fruits: Extraction of Antioxidants, Phenolic Content, and Radical Scavenging Determination: A Review. Antioxidants 2017, 6, 7.

(17) Selvamuthukumaran, M.; Shi, J. Recent Advances in Extraction of Antioxidants from Plant By-Products Processing Industries. Food Quality and Safety; Oxford University Press March, 2017, 1, pp 61-81.
(18) Mäki-Arvela, P.; Hachemi, I.; Murzin, D. Y. Comparative Study of the Extraction Methods for Recovery of Carotenoids from Algae: Extraction Kinetics and Effect of Different Extraction Parameters. J. Chem. Technol. Biotechnol. 2014, 89, 1607-1626.

(19) Imbimbo, P.; D’Elia, L.; Liberti, D.; Olivieri, G.; Monti, D. M. Towards Green Extraction Methods from Microalgae Learning from the Classics. Applied Microbiology and Biotechnology; Springer Science and Business Media Deutschland GmbH November, 2020, Vol.104; pp 9067-9077.

(20) Du, Y.; Schuur, B.; Kersten, S. R. A.; Brilman, D. W. F. Opportunities for Switchable Solvents for Lipid Extraction from Wet Algal Biomass: An Energy Evaluation. Algal Res. 2015, 11, 271-283.

(21) Peng, L.; Fu, D.; Chu, H.; Wang, Z.; Qi, H. Biofuel Production from Microalgae: A Review. Environ. Chem. Lett. 2020, 18, 285-297.

(22) Liu, H.; Huang, W.-C.; Guo, N.; Mao, X. Application of Secondary Amine Switchable Hydrophilicity Solvents for Astaxanthin Extraction from Wet Haematococcus pluvialis. Algal Res. 2020, 48, 101892.

(23) Sanzo, G.; Mehariya, S.; Martino, M.; Larocca, V.; Casella, P.; Chianese, S.; Musmarra, D.; Balducchi, R.; Molino, A. Supercritical Carbon Dioxide Extraction of Astaxanthin, Lutein, and Fatty Acids from Haematococcus pluvialis Microalgae. Mar. Drugs 2018, 16, 334.

(24) Imbimbo, P.; Bueno, M.; D’Elia, L.; Pollio, A.; Ibañez, E.; Olivieri, G.; Monti, D. M. Green Compressed Fluid Technologies To Extract Antioxidants and Lipids from Galdieria phlegrea in a Biorefinery Approach. ACS Sustainable Chem. Eng. 2020, 8, 2939-2947.

(25) Pawliszyn, J. Kinetic Model of Supercritical Fluid Extraction. J. Chromatogr. Sci. 1993, 31, 31-37.

(26) Jessop, P. G.; Heldebrant, D. J.; Li, X.; Eckert, C. A.; Liotta, C. L. Reversible nonpolar-to-polar solvent. Nature 2005, 436, 1102.

(27) Phan, L.; Andreatta, J. R.; Horvey, L. K.; Edie, C. F.; Luco, A.-L.; Mirchandani, A.; Darensbourg, D. J.; Jessop, P. G. Switchable-Polarity Solvents Prepared with a Single Liquid Component; ACS Publications, 2007.

(28) Du, Y.; Schuur, B.; Samorì, C.; Tagliavini, E.; Brilman, D. W. F. Secondary Amines as Switchable Solvents for Lipid Extraction from Non-Broken Microalgae. Bioresour. Technol. 2013, 149, 253-260.

(29) Du, Y.; Schuur, B.; Brilman, D. W. F. Maximizing Lipid Yield in Neochloris oleoabundans Algae Extraction by Stressing and Using Multiple Extraction Stages with N-Ethylbutylamine as Switchable Solvent. Ind. Eng. Chem. Res. 2017, 56, 8073-8080.

(30) Cicci, A.; Sed, G.; Jessop, P. G.; Bravi, M. Circular Extraction: An Innovative Use of Switchable Solvents for the Biomass Biorefinery. Green Chem. 2018, 20, 3908-3911.

(31) Du, Y.; Cyprichová, V.; Hoppe, K.; Schuur, B.; Brilman, W. Process Evaluation of Swing Strategies to Recover N-Ethylbutylamine after Wet Lipid Extraction from Microalgae. Sep. Purif. Technol. 2020, 233,115819 .

(32) Ismail, M.; Al-Zuhair, S. Thermo-Responsive Switchable Solvents for Simultaneous Microalgae Cell Disruption, Oil Extraction-Reaction, and Product Separation for Biodiesel Production. Biocatal. Agric. Biotechnol. 2020, 26, 101667.

(33) Davies, F. K.; Fricker, A. D.; Robins, M. M.; Dempster, T. A.; McGowen, J.; Charania, M.; Beliaev, A. S.; Lindemann, S. R.; Posewitz, M. C. Microbiota Associated with the Large-Scale Outdoor Cultivation of the Cyanobacterium Synechococcus sp. Algal Res. 2021, 58, 102382.

(34) D’Elia, L.; Del Mondo, A.; Santoro, M.; De Natale, A.; Pinto, G.; Pollio, A. Microorganisms from Harsh and Extreme Environments: A Collection of Living Strains at ACUF (Naples, Italy). Ecol. Quest. 2018, 29, 63-74.

(35) Wu, H.-L.; Wang, G.-H.; Xiang, W.-Z.; Li, T.; He, H. Stability and Antioxidant Activity of Food-Grade Phycocyanin Isolated from Spirulina platensis. Int. J. Food Prop. 2016, 19, 2349-2362.

(36) Bligh, E. G.; Dyer, W. J. A Rapid Method of Total Lipid Extraction and Purification. Can. J. Biochem. Physiol. 1959, 37, 911917.

(37) Rigano, M. M.; Raiola, A.; Tenore, G. C.; Monti, D. M.; Del Giudice, R.; Frusciante, L.; Barone, A. Quantitative Trait Loci Pyramiding Can Improve the Nutritional Potential of Tomato 
(Solanum lycopersicum) Fruits. J. Agric. Food Chem. 2014, 62, 1151911527.

(38) Petruk, G.; Gifuni, I.; Illiano, A.; Roxo, M.; Pinto, G.; Amoresano, A.; Marzocchella, A.; Piccoli, R.; Wink, M.; Olivieri, G.; et al. Simultaneous Production of Antioxidants and Starch from the Microalga Chlorella sorokiniana. Algal Res. 2018, 34, 164-174.

(39) Ferraro, G.; Imbimbo, P.; Marseglia, A.; Illiano, A.; Fontanarosa, C.; Amoresano, A.; Olivieri, G.; Pollio, A.; Monti, D. M.; Merlino, A. A Thermophilic C-Phycocyanin with Unprecedented Biophysical and Biochemical Properties. Int. J. Biol. Macromol. 2020, 150, 38-51.

(40) Petruk, G.; Raiola, A.; Del Giudice, R.; Barone, A.; Frusciante, L.; Rigano, M. M.; Monti, D. M. An Ascorbic Acid-Enriched Tomato Genotype to Fight UVA-Induced Oxidative Stress in Normal Human Keratinocytes. J. Photochem. Photobiol. B Biol. 2016, 163, 284-289.

(41) Vidussi, F.; Claustre, H.; Bustillos-Guzmàn, J.; Cailliau, C.; Marty, J.-C. Determination of Chlorophylls and Carotenoids of Marine Phytoplankton: Separation of Chlorophyll a from Divinylchlorophyll a and Zeaxanthin from Lutein. J. Plankton Res. 1996, 18, 2377-2382.

(42) Mantoura, R. F. C.; Repeta, D. J. Calibration Methods for HPLC; Jeffrey, S. W.; Mantoura, R. F. C.; Wright, S. W., eds.; UNESCO Publ., Paris: 1997, 407-428.

(43) Callieri, C. Synechococcus Plasticity under Environmental Changes. FEMS Microbiol. Lett. 2017, 364, 1-8.

(44) Hoiczyk, E.; Hansel, A. Cyanobacterial Cell Walls: News from an Unusual Prokaryotic Envelope. J. Bacteriol. 2000, 182, 1191-1199.

(45) Samorì, C.; López Barreiro, D.; Vet, R.; Pezzolesi, L.; Brilman, D. W. F.; Galletti, P.; Tagliavini, E. Effective Lipid Extraction from Algae Cultures Using Switchable Solvents. Green Chem. 2013, 15, 353-356.

(46) Fabrowska, J.; Messyasz, B.; Szyling, J.; Walkowiak, J.; Łęska, B. Isolation of Chlorophylls and Carotenoids from Freshwater Algae Using Different Extraction Methods. Phycol. Res. 2018, 66, 52-57.

(47) Assunção, M. F. G.; Amaral, R.; Martins, C. B.; Ferreira, J. D.; Ressurreição, S.; Santos, S. D.; Varejão, J. M. T. B.; Santos, L. M. A. Screening Microalgae as Potential Sources of Antioxidants. J. Appl. Phycol. 2017, 29, 865-877.

(48) Guedes, A.; Gião, M.; Seabra, R.; Ferreira, A.; Tamagnini, P.; Moradas-Ferreira, P.; Malcata, F. Evaluation of the Antioxidant Activity of Cell Extracts from Microalgae. Mar. Drugs 2013, 11, 1256-1270. 